\title{
MUTU IKAN NILA (Oreochromis Niloticus) SEGAR SECARA ORGANOLEPTIK YANG DIAWETKAN MENGGUNAKAN LARUTAN DAUN MATOA (Pometia Pinnata)
}

\author{
Tomi J. Ladja*1, Rieny Sulistijowati ${ }^{1}$, Rita Marsuci Harmain ${ }^{1}$ \\ 1 Jurusan Teknologi Hasil Perikanan, Fakultas Perikanan dan Ilmu Kelautan, Universitas Negeri Gorontalo, \\ JI.Jenderal Sudirman No.06, Kota Gorontalo 96128, Gorontalo, Indonesia \\ *Korespondensi: Tomiladja91@gmail.com \\ (Diterima 06-04-2020 / Dipublikasi 06-04-2020)
}

\begin{abstract}
ABSTRAK
Penelitian ini dilakukan dengan tujuan untuk mengetahui penghambatan kemunduran mutu ikan nila (Oreochromis niloticus) segar secara organoleptik yang diawetkan dengan menggunakan larutan daun matoa (Pometia pinnata). Perlakuan yang diberikan yaitu ada 3 taraf yaitu kosentrasi $5 \%, 10 \%$ dan 15\%. Analisis data menggunakan data Probability panelis. Berdasarkan hasil penelitian menunjukkan bahwa penggunaan larutan daun matoa dengan kosentrasi $15 \%$ mampu mempertahankan mutu ikan nila segar selama penyimpanan 12 jam secara organoleptik mutu hedonik dengan kreteria kenampakan mata dinilai oleh $60 \%$ panelis bola mata rata, kornea dan pupil jernih, agak mengkilap spesifik jenis ikan, Insang $60 \%$ panelis menilai warna insang merah tua atau coklat kemerahan, kurang cemerlang dengan sedikit lendir transparan, Lendir dikatakan oleh $56 \%$ panelis yaitu lapisan lendir mulai agak keruh, Daging masih dinilai baik karena 40\% panelis mengatakan bahwa sayatan daging cemerlang spesifik jenis, jaringan daging kuat, Bau yang dikatakan oleh $60 \%$ panelis yaitu masih termasuk segar, spesifik jenis kurang, dan tekstur masih dapat diterima karena padat, kompak, elastis.
\end{abstract}

Kata kunci: Pometia pinnata, Orechromis niloticus, Mutu Organoleptik

\section{ABSTRACT}

This research was conducted with the aim to determine the inhibition of organoleptic quality decline of fresh tilapia (Oreochromis niloticus) preserved using a matoa leaf solution (Pometia pinnata). Perlakuan yang diberikan yaitu ada 3 taraf yaitu kosentrasi $5 \%, 10 \%$ dan $15 \%$. Analisis data menggunakan data Probability panelis. Based on the results of the study showed that the use of a solution of matoa leaves with a concentration of $15 \%$ was able to maintain the quality of fresh tilapia for 12 hours storage organoleptically hedonic quality with the appearance of eye criteria assessed by $60 \%$ panelists flat eyeball, cornea and clear pupils, shiny specific species of fish, $60 \%$ of panelists judged the color of dark red or reddish brown gills, less brilliant with a little transparent mucus, Slime was said by $56 \%$ of panelists ie the mucous layer began to become slightly turbid, the flesh was still considered good because $40 \%$ of panelists said that the specific type of brilliant flesh incision, strong meat tissue, Odor said by $60 \%$ of panelists that is still included fresh, lack specific species, and texture is still acceptable because it is dense, compact, elastic.

Keywords: Pometia pinnata, Orechromis niloticus, Organoleptic Quality 


\section{PENDAHULUAN}

Ikan nila (Oreochromis niloticus) merupakan salah satu komoditas unggulan budidaya perikanan. Data produksi Provinsi Gorontalo menyatakan bahwa potensi ikan nila pada tahun 2016 mencapai 9.933,19 ton (DKP Provinsi Gorontalo, 2016). Secara umum di daerah Gorontalo ikan nila hanya dipasarkan dipasar-pasar lokal masyarakat dan ada juga yang dijual di pinggiran jalan dalam keadaan mati yang biasanya hanya diletakkan diatas meja tanpa dilakukan perlakuan pengawetan apapun. Tanpa diketahui tempat yang dijadikan tempat jual adalah salah satu tempat yang terbuka sehingga dapat berpengaruh terhadap ikan nila cepat mengalami penurunan mutu secara fisik maupun mikrobiologi yang dipengaruhi oleh lingkungan seperti udara dan suhu dari sinar matahari.

Menurut Devi (2015), ikan nila merupakan bahan pangan yang cepat mengalami kerusakan dan pembusukan (persihable food). Ikan nila mulai mengalami penurunan kualitas fisik setelah 2 jam kematian, kerusakan ini dapat terjadi secara biokimia maupun mikrobiologi, hal ini disebabkan oleh beberapa hal seperti kondisi lingkungan yang sangat sesuai untuk pertumbuhan mikroba pembusuk yang diakibatkan oleh bakteri maupun jamur. Sehingga secepat mungkin dilakukan pengawetan.

Pengawetan bertujuan untuk menghambat pertumbuhan mikroba pada ikan sehingga

http://ejurnal.ung.ac.id/index.php/jfpj/issue/archive dapat memperpanjang masa simpan bahan pangan. Pengawetan alami merupakan salah satu metode penghambatan pertumbuhan mikroorganisme pada ikan dengan menggunakan bahan alami yang mengandung senyawa bioaktif.

Rofik dan Riwayati (2013) menyatakan bahwa, tumbuhan dapat dimanfaatkan oleh masyarakat sebagai pengawet alami yang berasal dari alam, dari tumbuhan mengandung setidaknya ada empat senyawa yang memiliki sifat mengawetkan. Keempat senyawa itu adalah saponin, tanin, alkaloid dan flavonoid. Senyawa-senyawa tersebut merupakan rangkaian senyawa yang mencegah perkembangan bakteri pembusuk atau disebut juga dengan antibakteri. Salah satu tumbuhan yang dapat dimanfaatkan untuk mengawetkan ikan adalah tumbuhan pertanian seperti daun matoa (Pometia pinnata). Kuspradini, dkk (2016) menyatakan bahwa ekstrak daun matoa (Pometia pinnata) memiliki kemampuan yang cukup kuat dalam menghambat pertumbuhan bakteri seperti Streptococcus mutans, Streptococcus sobrinus, Escherichia coli.

Matoa adalah tumbuhan bagian dari hasil pertanian yang mengandung senyawa bioaktif sebagai antibakteri yang saat ini belum dimanfaatkan oleh masyarakat. Sehingga penulis melakukan pnelitian ini untuk mengetahui penghambatan kemunduran mutu ikan nila (Oreochromis niloticus) segar secara organoleptik yang diawetkan dengan 
menggunakan larutan daun matoa (Pometia pinnata)

\section{METODE PENELITIAN}

\section{Waktu dan Tempat Penelitian}

Penelitian ini dilakukan pada bulan Januari sampai bulan Februari Tahun 2019. Pengujian organoleptik dilaksanakan di Laboratorium Bioteknologi dan Karakteristik Hasil Perikanan Fakultas Perikanan dan IImu Kelautan Universitas Negeri Gorontalo.

\section{Alat dan Bahan Pembuatan Larutan Daun Matoa}

Macam-macam alat yang digunakan pada penelitian ini adalah bak plastik, baskom plastik, blender, timbangan analitik, talanan plastik, panci, gelas ukur plastik $1000 \mathrm{~mL}$, dan saringan sedang serta bahan yang digunakan adalah daun matoa dan ikan nila segar.

\section{Alat dan Bahan Pengujian Organoleptik}

Alat yang digunakan untuk pengujian organoleptik menggunakan lembar score sheet organoleptik mutu hedonik ikan segar, polpen dan cater pisau. Bahan yang digunakan pengujian organoleptik adalah sampel ikan nila segar yang diberikan perlakuan.

\section{Metode Penelitian}

Metode yang digunakan untuk uji daya simpan ikan nila adalah menggunakan data Probability dengan perlakuan yang diberilakan yaitu $0 \%$ (kontrol) dan kosentrasi $5 \%$.
Parameter yang digunakan dalam penelitian ini adalah mutu organoleptik.

\section{Tahapan Penelitian}

Adapun tahapan penelitian dilakukan dengan dua tahap yaitu tahap pertama pembuatan larutan dan tahap kedua perendaman ikan pada larutan daun matoa dengan kosentrasi yang berbeda.

Adapun tahapan proses pembuatan larutan daun matoa menurut Devi (2015) yang dimodifikasi yaitu pengambilan daun matoa. Pengambilan sampel daun matoa berasal dari Kelurahan Kelurahan Tapa Jalan Rusli Datau Kecamatan Sipatana Kota Utara yang dipisahkan dari batangnya, penanganan daun matoa (pemilihan daun), perobekan yang dilakukan dengan cara menggunting daun matoa menjadi lembaran-lembaran kecil, pembuatan bubur daun matoa mengunakan mesin blender, pemanasan menggunakan panci perebusan, untuk mendapatkan ekstrak larutan daun matoa dilakukan penyaringan.

Hasil dari penyaringan larutan daun matoa digunakan untuk perendaman ikan nila segar dengan kosentrasi $5 \%, 10 \%$ dan $15 \%$, perendaman 30 menit lalu angkat disimpan selama 12 Jam dalam suhu kamar.

\section{HASIL DAN PEMBAHASAN}

\section{Analisis Mutu Organoleptik Ikan Nila (Oreochromis niloticus) \\ Uji mutu organoleptik yang dilakukan} merupakan pengujian ikan nila yang dilakukan penyimpanan selama 12 jam dengan diberikan 
kosentrasi $0 \%$ 5\% 10\% dan 15\%. Parameter pengujian mutu organoleptik ikan nila adalah kenampakan mata, insang, lendir, daging, bau dan tekstur. Pengujian mutu organoleptik ini dilakukan oleh panelis semi terlatih dengan jumlah 25 orang yang merupakan mahasiswa tehnologi hasil perikanan universitas negeri gorontalo.

\section{Hasil Analisis Organoleptik Ikan Nila (Oreochromis niloticus)}

Data probability panelis terhadap mutu organoleptik (hedonik) ikan nila (Oreochromis niloticus) pada kosentrasi larutan daun matoa $0 \%, 5 \%, 10 \%$ dan $15 \%$ dapat dilihat pada gambar histogram dibawah ini;

\section{Kosentrasi 0\%}

Data probability panelis terhadap mutu organoleptik (hedonik) ikan nila (Oreochromis niloticus) pada kosentrasi $0 \%$.

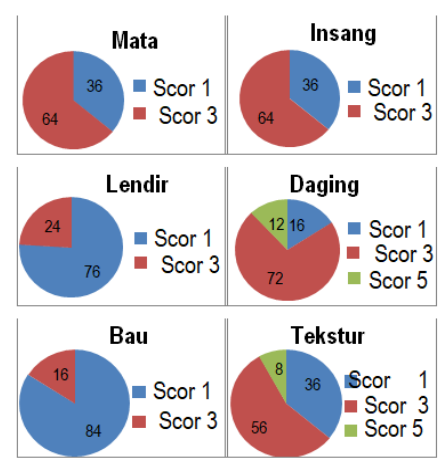

\section{Kosentrasi 5\%}

Data probability panelis terhadap mutu organoleptik (hedonik) ikan nila (Oreochromis niloticus) pada kosentrasi larutan daun matoa $5 \%$.

http://ejurnal.ung.ac.id/index.php/jfpj/issue/archive

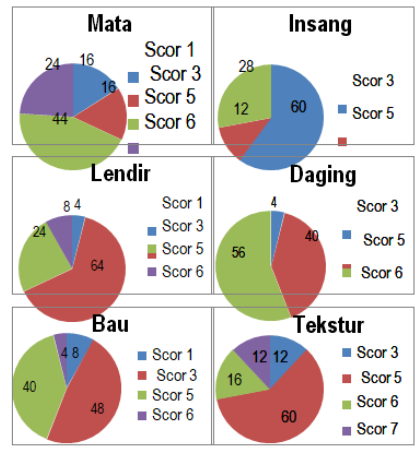

\section{Kosentrasi $10 \%$}

Data probability panelis terhadap mutu organoleptik (hedonik) ikan nila (Oreochromis niloticus) pada kosentrasi larutan daun matoa $10 \%$.

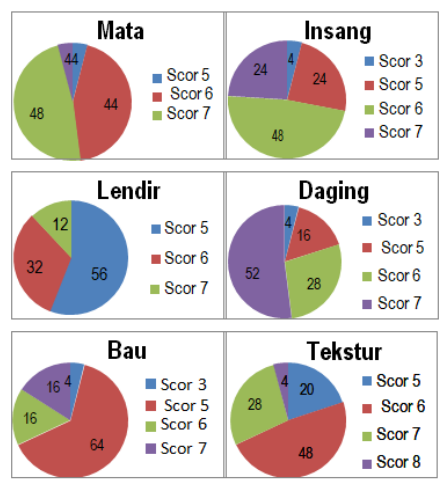

\section{Konsentrasi $15 \%$}

Data probability panelis terhadap mutu organoleptik (hedonik) ikan nila (Oreochromis niloticus) pada kosentrasi larutan daun matoa $15 \%$.

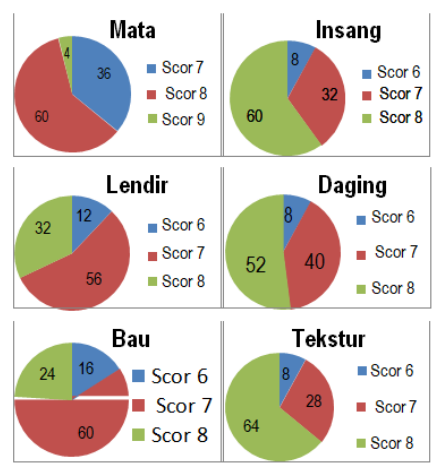


Berdasarkan penelitian pendahuluan yang telah dilakukan didapatkan hasil pengamatan dari tiga kosentrasi antara 5\%, 10\% dan 15\% yang digunakan untuk mempertahankan kualitas ikan nila yang diamati secara organoleptik, panelis menilai bahwa ikan nila yang diawetkan dengan kosentrasi larutan daun matoa 15\% masih dapat dikatakan baik. Spesifikasi pada kosentrasi $15 \%$ dengan kenampakan mata dinilai oleh $60 \%$ panelis bola mata rata, kornea dan pupil jernih, agak mengkilap spesifik jenis ikan, Insang 60\% panelis menilai warna insang merah tua atau coklat kemerahan, kurang cemerlang dengan sedikit lendir transparan, Lendir dikatakan oleh $56 \%$ panelis yaitu lapisan lendir mulai agak keruh, Daging masih dinilai baik karena 40\% panelis mengatakan bahwa sayatan daging cemerlang spesifik jenis, jaringan daging kuat, Bau yang dikatakan oleh $60 \%$ panelis yaitu masih termasuk segar, spesifik jenis kurang, dan tekstur masih dapat diterima karena padat, kompak, elastis.

\section{SIMPULAN}

Berdasarkan hasil penelitian menunjukkan bahwa penggunaan larutan daun matoa (Pometia pinnata) dengan kosentrasi $15 \%$ mampu mempertahankan mutu ikan nila (Oreochromis niloticus) segar selama penyimpanan 12 jam secara organoleptik mutu hedonik kenampakan mata dinilai oleh $60 \%$ panelis bola mata rata, kornea dan pupil jernih, agak mengkilap spesifik jenis ikan, Insang $60 \%$ panelis menilai warna insang merah tua atau coklat kemerahan, kurang cemerlang dengan sedikit lendir transparan, Lendir dikatakan oleh $56 \%$ panelis yaitu lapisan lendir mulai agak keruh, Daging masih dinilai baik karena $40 \%$ panelis mengatakan bahwa sayatan daging cemerlang spesifik jenis, jaringan daging kuat, Bau yang dikatakan oleh $60 \%$ panelis yaitu masih termasuk segar, spesifik jenis kurang, dan tekstur masih dapat diterima karena padat, kompak, elastis.

\section{DAFTAR PUSTAKA}

Devi, R, A. 2015. Pengawetan Ikan Nila (Oreochromis niloticus) Menggunakan Daun Sirih Dengan Variasi Lama Perendaman Yang Berbeda. Skripsi. Program Studi Pendidikan Biologi. Fakultas Keguruan Dan IImu Pendidikan Universitas Muhammadiyah Surakarta..

Dinas Perikanan Kelautan Provinsi Gorontalo. 2016. Data Perikanan Budidaya 2016. Gorontalo.

Kuspradini, H, Whicliffe F, P Dan Irawan, W, K. 2016. Aktivitas Antioksidan Dan Antibakteri Ekstrat Daun Matoa (Pometia pinnata). Jurnal. Fakultas Kehutanan. Universitas Mulawar. 